\title{
GAMBARAN PENGETAHUAN IBU TENTANG PERTOLONGAN PERTAMA KEGAWATDARURATAN DEMAN PADA BALITA DI POSYANDU SOKARAJA KULON
}

\author{
Nurul Fatwati Fitriana ${ }^{1}$ \\ Prodi Keperawatan S1, Fakultas Ilmu Kesehatan, \\ Universitas Muhammadiyah Purwokerto \\ Nurulfatwati90@gmail.com
}

\begin{abstract}
The incidence of fever in children in Indonesia is still quite high. Fever is when the body temperature rises by 38 celcius degree. Fever in children is one of the reasons parents seek medical help to treat it. Fever management is very important to reduce the negative impact caused by fever. This study aims to determine the description of mothers knowledge in first aid for fever emergencies in children. This research is a descriptive study and using a cross sectional approach. The population in this study were mothers who had toodlers aged 6 months to 5 years. The sample of this research is 20 respondent. The sampling technique used accidental sampling and data collection using a knowledge questionnaire of fever management with 16 questions. Data were analysed by univariate analysis. From the results of univariate analysis, it was found that the majority of the had a good knowledge category were 14 respondents (70\%), while the another had enough knowledge category 5 respondents (25\%), and poor knowledge were 1 respondent (5\%). The result of univariate analysis of this study indicate that majority of respondentt's knowledge in the good category (70\%). From the questonnaire show that all respondents would measure the children's temperature using a thermometer when he had a fever, the respondents take his child to seek medical help when he was sick, and apply warm compresses to the child with a fever.
\end{abstract}

Keyword : Fever, First aid, Knowledge

\begin{abstract}
ABSTRAK
Angka kejadian demam pada anak di Indonesia masih cukup tinggi. Demam merupakan peningkatan suhu tubuh diatas 38 derajad celcius. Demam pada anak merupakan salah satu alasan orang tua mencari bantuan medis untuk menanganinya. Penanganan demam menjadi sangat penting untuk mengurangi dampak negatif yang disebabkan oleh demam. Penelitian ini bertujuan untuk mengetahui gambaran pengetahuan ibu dalam melakukan pertolongan pertama pada kegawatdaruratan demam pada balita di Posyandu Sokaraja Kulon. Penelitian ini merupakan penelitian deskriptif dengan menggunakan pendekatan cross sectional. Populasi dalam penelitian ini adalah ibu yang mempunyai balita berusia 6 bulan sampai 5 tahun. Jumlah sampel dalam penelitian ini adalah 20 responden. Pengambilan sampel dilakukan dengan accidental sampling dan pengumpulan data menggunakan kuesioner pengetahuan penanganan demam berjumlah 16 soal. Analisis data menggunakan analisis univariat. Berdasarkan hasil analisis univariat didapatkan hasil bahwa dari 20 responden mayoritas mempunyai kategori pengetahuan yang baik yaitu 14 responden $(70 \%)$, sedangkan sisanya mempunyai kategori pengetahuan cukup 5 responden $(25 \%)$ dan kurang 1 responden (5\%). Hasil penelitian yang didapatkan adalah mayoritas pengetahuan responden dalam kategori baik (70\%). Dari kuesioner yang dibagikan menyatakan bahwa semua responden akan mengukur suhu anak menggunakan termometer ketika demam, membawa anaknya untuk mencari bantuan medis ketika sakit, dan melakukan kompres dengan air hangat pada anak yang demam.
\end{abstract}

Kata Kunci : Demam, Pengetahuan, Pertolongan Pertama

\section{PENDAHULUAN}

Demam atau hipertermia adalah kenaikan suhu tubuh diatas normal.
Kenaikan suhu tubuh merupakan bagian dari reaksi biologis kompleks, yang diatur dan dikontrol oleh susunan saraf pusat. Demam sendiri merupakan gambaran 
karakteristik dari kenaikan suhu tubuh oleh karena berbagai penyakit infeksi dan noninfeksi (Sarasvati, 2010). Kenaikan suhu badan tersebut bisa menjadi pertanda bahwa sistem imunitas anak berfungsi dengan baik atau merupakan tanda bahwa tubuh sedang melawan infeksi atau bakteri yang ada di dalam tubuh (Kristianingsih, 2018). Demam terjadi ketika tubuh memiliki suhu di atas normal $\left(>37^{\circ} \mathrm{C}\right)$. Demam dapat disebabkan oleh sistem termoregulasi yang terganggu.

World Health Organization (WHO) memperkirakan jumlah kasus Demam pada anak di seluruh dunia mencapai 1633 juta dengan 500-600 ribu kematian setiap tahunnya (Setyowati, 2013). Data kunjungan ke fasilitas kesehatan anak di Brazil, terdapat sekitar 19\% sampai 30\% anak diperiksa karena menderita Demam. Penelitian oleh Jalil, Jumah dan Al Baghli (2007) di Kuwait menunjukkan bahwa sebagian besar anak usia 3 bulan sampai 36 bulan mengalami serangan demam ratarata enam kali pertahunnya (Setiawati, 2007).

Di Asia, balita yang mengalami demam sekitar 10-15\% yang berhubungan dengan gejala-gejala atau tanda dari suatu penyakit (Graneto, 2010). Kejadian ini terjadi pada rentang usia 1 bulan sampai 5 tahun, dan insiden kejadian Demam paling banyak terjadi pasa usia $14-18$ bulan. Di Indonesia sendiri, dilaporkan angka kejadian hipertermia pada tahun 20122013 3-4\% dari anak yang berusia 6 bulan - 5 tahun (Wibisono,2015). Demam sangat berhubungan dengan usia, hampir tidak pernah ditemukan sebelum usia 6 bulan dan setelah 6 tahun (Hull, 2010).

Batas suhu tubuh dinyatakan demam berbeda apabila tempat pengukurannya berbeda. Pengukuran suhu tubuh di berbagai tubuh memiliki batasan nilai atau derajad demam yaitu di axila/ketiak >37 derajad celcius, suhu oral $>37,5$ derajad celcius, suhu rektal/anus $>38$ derajad celcius, suhu dahi dan membran telinga diatas 38 derajad celcius (Mansur, 2014). Peningkatan suhu tubuh yang parah dan dengan durasi yang cukup panjang dapat menimbulkan kerusakan pada tubuh.

Sebagian besar kasus demam pada bayi disebabkan oleh infeksi akut, yang bersifat lokal atau sistemk. Penyebab yang lebih jarang meliputi penyakit kolagen vascular, neoplasma dan kelainan neurologis. Kasus demam dengan penyebab yang tidak diketahui secara khas ditandai oleh demam selama 2 minggu atau lebih tanpa tanda-tanda lokal atau diagnose spesifik, memerlukan perhatian dan pola, frekuensi dan tingginya temperatur sepanjang waktu (Lisnawati, 2013).

Prognosis atau perjalanan penyakitpenyakit bergantung pada penanganan awal demam terutama dalam menurunkan suhu tubuh. Petugas kesehatan maupun orang awam perlu mengetahui penanganan yang tepat dalam mengatasi hipertermia. Apabila tidak ditangani dengan baik, maka dapat mengakibatkan kerusakan rangkaian khususya sistem saraf pusat dan otot, sehingga mengakibatkan kematian. Kenaikan suhu yang mencapai 41 derajad celcius angka kematiannya mencapai 17 $\%$, suhu $43^{\circ}$ celcius akan koma dengan angka $70 \%$, dan pada suhu $45,5^{\circ}$ celcius akan meninggal dalam beberapa jam (Suryaningsih, 2013). Wilderness Medical Society (2013) telah menerbitkan panduan dalam pencegahan dan penanganan penyakit akibat panas.

Penanganan perta pada demam dapat berupa terapi farmakologi dan non farmakologi. Terapi farmakologi yang digunakan biasanya adalah berupa memberikan obat penurun panas. Sedangkan terapi non farmakologi yang dapat digunakan yaitu dengan menggunakan beberapa prinsip perpindahan panas (konduksi, konveksi dan Evaporasi), lebih sering minum, banyak istirahat, mandi dengan air hangat serta memberi kompres (Saito, 2013).

Penanganan pertama yang harus dilakukan adalah memastikan sirkulasi, jalur napas, dan pernapasan (disingkat $\mathrm{CAB})$ tidak terganggu dan stabil. 
Kemudian lakukan penurunan suhu tubuh pasien target penurunan hingga $<38^{\circ} \mathrm{C}$ ).

Penanganan yang lain adalah dengan memberi minum yang banyak agar tidak dehidrasi. Mitos yang masih dipercayai adalah balita sakit tidak boleh minum es, padahal hal itu diperbolehkan, asalkan banyak cairan masuk untuk mencegah dehidrasi. Minuman beralkohol tidak diperbolehkan dikonsumsi karena menghambat penguapan (Sheehy, 2018).

Demam menimbulkan ketakutan sendiri pada ibu. Hasil penelitian Setyani (2014) memperlihatkan bahwa $80 \%$ orang tua mempunyai fobia demam. Mereka mengira bila demam tidak segera diobati maka demam akan semakin tinggi. Konsep yang salah ini, banyak orang tua mengobati demam ringan yang sebetulnya tidak perlu diobati.

Peran ibu merupakan hal yang sangat penting, khususnya dalam perilaku dalam perawatan demam karena penggunaan sarana kesehatan untuk balita berkaitan erat dengan perilaku ibu tentang kesehatan. Demam pada anak merupakan suatu keadaan yang sering menimbulkan kecemasan, stress dan fobia tersendiri bagi orang tua. Oleh karena ibu harus tahu tentang pengertian demam, tanda dan gejala demam dan penanganan demam anak sehingga ibu dapat melakukan upayaupaya untuk menurunkan demam Penanganan demam pada balita sangat tergantung pada orang tua terutama ibu. Ibu adalah sosok yang penuh pengertian dalam hal mengasuh, membimbing dan mengawasi perkembangan anaknya ke arah yang lebih baik (Harjaningrum, 2014). Karakteristik ibu merupakan salah satu bagian yang dapat menunjang pencegahan demam pada anak. Begitu juga ketika anak mengalami demam, ibu harus mempunyai sikap yang baik dalam memberikan perawatan, dapat menumbuhkan penanganan yang terbaik bagi anaknya (Notoatmojo, 2012).

Menurut studi pendahuluan pada beberapa ibu di Posyandu, masih ada yang belum jelas mengenai penanganan demam pada anak. Salah satu tugas ibu sebagai madrasah pertama bagi anak-anaknya dan pemberian pertolongan pertama bagi keluarganya apabila terjadi salah satu yang sakit. Peran seorang ibu bertanggung jawab dalam mengasuh dan menjaga keluarga dari kejadian yang membahayakan (Sari, Wulandini, \& Fitri, 2018).

\section{METODE}

Penelitian ini menggunakan metode kuantitatif dengan rancangan deskriptif. Lokasi penelitian di Posyandu Sokaraja Kulon dan penelitian dilakukan bulan April 2021. Populasi penelitian adalah ibu-ibu dengan anak balita usia 6 bulan sampai 5 tahun. Jumlah sampel yang diambil adalah 20 responden, pengambilan sampel menggunakan metode accidental sampling. Variabel penelitian tunggal yaitu gambaran pengetahuan ibu dalam penanganan demam. Data dikumpulkan menggunakan kuesioner pengetahuan yang berisi 16 pertanyaan yang meliputi definisi demam, pencegahan demam, faktor penyebab demam dan penatalaksanaan demam. Analisa data yang digunakan adalah analisa data univariat untuk mengetahui kategori pengetahuan responden.. Pengetahuan responden dalam penanganan demam pada anak dibagi menjadi 3 yaitu kurang, cukup dan baik. Penelitian ini telah mendapatkan ijin etik dari Komite Etik Fakultas Ilmu Kesehatan Universitas Muhammadiyah Purwokerto dengan nomor etik KEP/UMP/04/II/2021.

\section{HASIL}

Penelitian ini dilakukan di Posyandu Sokaraja Kulon Kecamatan Sokaraja. Jumlah responden yang ikut berpartisipasi pada penelitian ini adalah 20 orang ibu.

\section{Karakteristik Responden}

Karakteristik responden terdiri dari usia dan pekerjaan responden. Usia 
responden diantara usia 22 tahun sampai 45 tahun. Pekerjaan responden dikelompokkan menjadi Ibu rumah tangga, wiraswasta dan buruh/tani. Kriteria tersebut dapat dilihat dalam tabel berikut :

\section{Tabel 1. Distribusi Karakteristik} Responden

\begin{tabular}{cc}
\hline Variabel & \\
\cline { 2 - 2 } & \\
\hline Umur & \\
Mean \pm SD & $32 \pm 34$ \\
Min-Max & $22-45$ \\
\hline Pekerjaan & \\
IRT & 16 \\
Wiraswasta & 4 \\
Buruh/Tani & 0 \\
\hline Total & $\mathrm{n}=20$ \\
\hline
\end{tabular}

Berdasarkan tabel 1, diperoleh hasil usia rata-rata responden adalah 32 tahun, dengan usia paling muda 22 tahun dan paling tua berusia 45 tahun. Mayoritas pekerjaan responden adalah ibu rumah tangga.

\section{Tabel 2. Gambaran Pengetahuan Pertolongan Pertama Kegawatdaruratan Demam Pada Balita}

\begin{tabular}{ccc}
\hline Variabel & Frekuensi & Presentase \\
\hline Pengetahuan & & \\
\hline Baik & 14 & $70 \%$ \\
\hline Cukup & 5 & $25 \%$ \\
\hline Kurang & 1 & $5 \%$ \\
\hline Total & 20 & $100 \%$
\end{tabular}

Berdasarkan tabel 2, diperoleh hasil bahwa mayoritas responden mempunyai pengetahuan yang baik tentang pertolongan pertama penanganan demam balita, sisanya 5 orang mempunyai pengetahuan yang cukup (25\%) dan pengetahuan buruk (5\%).

\section{PEMBAHASAN}

Demam merupakan keadaan suhu tubuh di atas 38 derajad celcius, merupakan respon alami tubuh ketika tubuh terdapat infeksi dan merupakan tanda sakit yang biasa pada anak-anak
(The Royal Children's Hospital General Medicine and Emergency Departement and Centre for Community Child Health, 2018). Pada kuesioner yang di sebarkan oleh peneliti, pertanyaan definisi demam dijawab benar oleh $65 \%$ responden. Menurut Anokye, Acheampong, Gyamfi, \& Budu-ainooson, (2018), responden mengatakan bahwa penyebab demam adalah malaria, infeksi, kelebihan makan dan karena gangguan makhluk halus. Selain itu, responden juga menilai tandatanda demam adalah suhu badan yang panas, menggigil, bayi yang diam, bayi yang sering menangis, dan bayi yang banyak tidur.

Mayoritas responden dalam penelitian ini mempunyai pengetahuan baik dalam penanganan demam pada anak, yaitu 14 responden (70\%). Menurut Anokye et al., (2018), pengetahuan yang baik, buruk ataupun kurang tentang penanganan demam pada anak pada responden bisa dipengaruhi oleh beberapa faktor. Faktor tersebut adalah usia responden, usia anak, jumlah anak, dan tingkat pendidikan ibu.pada penelitian ini, didapatkan 53\% pengetahuan ibu baik. Persamaan penelitian Anokye et al., (2018) dan penelitian yang dilakukan adalah samasama meneliti pengetahuan penanganan demam yang pada ibu-ibu dengan anak dibawah 5 tahun.

Sebanyak $25 \%$ responden mempunyai pengetahuan yang cukup dan $5 \%$ responden mempunyai pengetahuan yang kurang. Penelitian yang sama dilakukan oleh Anokye et al., (2018), menunjukkan bahwa $43 \%$ responden mempunyai pengetahuan yang kurang. Hal ini bisa disebabkan karena ibu tidak berpendidikan tinggi, miskin dan mungkin tidak mempunyai akses ke fasilitas kesehatan yang memadai.

Dari kuesioner yang disebarkan, semua responden mempunyai termometer di rumah. Menurut Villarejo-Rodríguez María Gloria \& Beatriz, (2019), terdapat 2 cara mengukur suhu tubuh, yaitu menggunakan termometer dan 
menggunakan tangan. Termometer terdiri dari beberapa jenis yaitu manual dan digital.

Demam pada anak merupakan salah satu alasan yang membuat orang tua membawa anaknya mencari bantuan pengobatan medis dalam 24 jam pertama mengalami demam. Demam dianggap sebagai indikasi sakit yang serius dan berpotensial membahayakan kehidupan anak (Urbane, Likopa, Gardovska, \& Pavare, 2019). Pada beberapa pertanyaan pada bagian penatalaksanaan demam, semua responden akan segera membawa anaknya ke Puskesmas/Rumah sakit bila anaknya sakit dan tidak kunjung sembuh. Selain itu, semua responden akan memeriksakan kondisi anaknya jika sedang sakit ke dokter. Selain itu, tindakan orang tua juga akan memijatkan anaknya jika anaknya sakit sebanyak 50\%. Menurut Anokye et al., (2018), alasan orang tua membawa anaknya ke rumah sakit atau klinik ketika anak demam adalah karena mereka mencari ahli dalam penanganan demam pada anak. Menurut VillarejoRodríguez María Gloria \& Beatriz, (2019) $30 \%$ pasien berkonsultasi dengan dokter anak dikarenakan demam.

Responden mengatakan bahwa ketika anaknya demam akan mengompres menggunakan air hangat ada $85 \%$. Penelitian yang dilakukan oleh Anokye et al., (2018) bahwa penanganan demam salah satunya dengan kompres hangat dan tepid sponging, mengaplikasikan pengobatan herbal dan mengunjungi klinik. Mayoritas responden memberikan obat herbal, paracetamol, dan klorokuin sebagai pengobatan dalam penanganan demam.

Semua responden dalam penelitian ini mengatakan bahwa mereka selalu memberikan obat penurun panas dirumah apabila anaknya demam. Dalam penelitian Villarejo-Rodríguez María Gloria \& Beatriz, (2019) orangtua secara cepat memberikan antipitetik untuk mengurangi komplikasi yang di akibatkan demam.
Ketika suhu tubuh anak naik, mayoritas orangtua menjadi khawatir apabila demam akan membahayakan diri anak (Abdinia, Hassan, \& Khalilzadeh, 2017). Usia ibu, usia anak, jumlah anak dan tingkat pendidikan menjadi faktor yang berhubungan dengan pengetahuan ibu dalam menangani demam. Orang tua harus diedukasi akibat demam, khususnya jika tidak ditangani tepat waktu, dan memperhatikan penatalaksanaan demam secara dini (Anokye et al., 2018). Faktor lain yang berpengaruh dalam penatalaksanaan demam adalah pengalaman dalam menangani demam pada anak sebelumnya, dukungan dari lingkungan keluarga, ibu yang bekerja di luar rumah, dan pengalaman orang tua dalam mendapatkan pelatihan penanganan demam (Villarejo-Rodríguez María Gloria \& Beatriz, 2019).

\section{KESIMPULAN}

Mayoritas pengetahuan ibu dalam penanganan kegawatdaruratan demam pada balita pada penelitian ini adalah baik yaitu $70 \%$, sedangkan yang lain cukup (25\%) dan kurang (5\%). Dari kuesioner yang disebarkan, didapatkan data bahwa dalam penanganan demam, semua responden akan mengukur demam menggunakan termometer, membawa ke klinik atau ke rumah sakit apabila anak demam, dan akan mengompres dengan air hangat apabila anak demam.

\section{UCAPAN TERIMAKASIH}

Peneliti mengucapkan terimakasih kepada pihak yang telah banyak membantu dalam pengambilan data, dan terimakasih kepada Lembaga Penelitian dan Pengabdian Masyarakat Universitas Muhammadiyah Purwokerto yang telah membiayai penelitian ini. 


\section{DAFTAR PUSTAKA}

Abdinia, B., Hassan, M., \& Khalilzadeh, H. (2017). Assessment of Knowledge and Performance of the Parents at the Management of Fever in Children, 5(48), 6485-6493. http://doi.org/10.22038/ijp.2017.268 76.2317

Anokye, R., Acheampong, E., Gyamfi, N., \& Budu-ainooson, A. (2018). Pediatric Research Childhood Fever Knowledge and Management: A Case of Moth - ers with Children under Five Years, (December). http://doi.org/10.23937/24695769/1510044

Ellena \& Prakoso. 2015. Pengaruh Penggunaan Telemedicine (Aplikasi Berbasis Internet) Terhadap Kepatuhan Minum Obat Pada Pasien Diabetes Melitus Tipe 2. Skripsi. Universitas Yogyakarta.

Harjaningrum, 2014. Mengupas Rahasia Menjadi Pasien cerdas. Jakarta : Mizan

Hull. (2008). Pengaruh Pendidikan Kesehatan tentang Penanganan Kejang Demam menggunakan Audio Visual Terhadap Tingkat Pengetahuan dan Sikap Ibu dengan Anak Riwayat Kejang Demam. (Skripsi). Stikes Kusuma Husada. Program Studi S1 Keperawatan, Surakarta. Diunduh di http://stikeskusumahusada.ac.id/skrip si.pdf

Kristianingsih (2018). Hubungan Tingkat Pengetahuan Ibu Tentang Demam dengan Penanganan Demam Pada Bayi 0-12 Bulan di Desa Datarajan Wilayah Kerja Puskesmas Ngarip Kabupaten Tanggamus Tahun 2018. Midwifery Journal. Vol 4 No 1 Januari 2019.

Lisnawati. 2014. Hubungan Pengetahuan dan Sikap Ibu Tentang demam pada Balita di Wilayah Kerja Puskesmas Kota Jambi. Stikes Prima Jambi
Mansur, A.R. 2014. Perawatan Demam pada Anak

Notoatmojo, 2012. Pendidikan dan Perilaku Kesehatan. Jakarta : Rineka Cipta

Rodriguez, M.G.V., \& Martin., B.R. (2019). Parental Approach to the Management of Childhood Fever : Differences between Health Professional and Non-Health Professional Parents. International Journal of Environmental Research and Public Health (16). p1-10.

Saito, M. 2013. Mukjizat Suhu Tubuh. Jakarta : PT Gramedia

Sarasvati LD. 2010. Status Resistensi Larva Aedes aegypti (Linnaeus) terhadap Temephos (Studi di Kelurahan Jatiasih Kecamatan Jatiasih Kota Bekasi Provinsi Jawa Barat). 4. 2016;1Urbane, U.N. et al., 2019. Beliefs, Practices and Health Care Seeking Behavior of Parents Regarding Fever in Children. , pp.112.

Sari, E. M. D., Wulandini, P., \& Fitri, A. (2018). Perilaku Ibu DAlam Pertolongan Pertama Saat Tersedak Pada Anak Usia Toodler di Posyandu HArapan Ibu Desa Penghidupan Tahun 2018. Jurnal Keperawatan Abdurrab, 2(1), 74-84

Setyani. 2014. Gambaran Prilaku Ibu dalam Penanganan Demam Pada Anak di Desa Seren Kecamatan Purworejo. Digilib. Unisayogya.ac.id / 549Sheehy. 2018. Keperawatan Gawat Darurat dan Bencana. Jakarta : EGC

Suryaningsih. 2013. Penanganan Demam Pada Bayi Balita. Diakses pada 19 Oktober 2020

The Royal Children's Hospital General Medicine and Emergency departement and Center for Community Child Health. Fever in Children (In Internet). The Royal 
Children's Hospital Melbourne (2018).

Urbane, U. N., Likopa, Z., Gardovska, D., \& Pavare, J. (2019). Beliefs, Practices and Health Care Seeking Behavior of Parents Regarding Fever in Children, 1-12 